\title{
First record of tail bifurcation in Lygodactylus klugei (Smith, Martin \& Swain, 1977) (Sauria: Gekkonidae), with comments on caudal adhesive pads
}

\author{
Antônio Rafael Lima Ramos ${ }^{1,2}$ * \\ John Allyson Andrade Oliveira ${ }^{1}$ \\ Margarida Maria Xavier da Silva ${ }^{1,2}$ \\ Robson Victor Tavares ${ }^{1,3}$ \\ Diva Maria Borges-Nojosa ${ }^{1,2,3}$ \\ Universidade Federal do Ceará \\ ${ }^{1}$ Núcleo Regional de Ofiologia, Centro de Ciências, Bloco 905 \\ Avenida Humberto Monte, Pici, CEP 60.440-900, Fortaleza - CE, Brazil \\ 2 Programa de Pós-Graduação em Sistemática, Uso e Conservação da Biodiversidade \\ ${ }^{3}$ Programa de Pós-Graduação em Ecologia e Recursos Naturais \\ * Corresponding author \\ herpetoramos@gmail.com
}

Submetido em 15/07/2021

Aceito para publicação em 13/10/2021

\section{Resumo}

Primeiro registro de bifurcação da cauda em Lygodactylus klugei (Smith, Martin \& Swain, 1977) (Sauria: Gekkonidae) com comentários sobre as almofadas adesivas caudais. O processo de regeneração caudal em lagartos nem sempre ocorre perfeitamente, podendo ocasionar algumas anormalidades como o surgimento de caudas empenadas ou supranumerárias. Aqui relatamos os primeiros casos de bifurcação da cauda na lagartixa anã Lygodactylus klugei e trazemos observações sobre as almofadas adesivas caudais nos indivíduos com cauda bifurcada. Nossos registros representam um novo caso de bifurcação caudal em espécies de lagartos que apresentam caudas com especializações funcionais e estruturas morfológicas elaboradas, sendo os primeiros registros desse tipo de anomalia para o gênero Lygodactylus.

Palavras-chave: Anomalias da cauda; Autotomia; Lagartos; Regeneração da cauda

\section{Abstract}

The process of caudal regeneration in lizards does not always occur perfectly, which can cause some abnormalities, such as the appearance of warped or supernumerary tails. Here we report the first cases of tail bifurcation in the Dwarf Gecko, Lygodactylus klugei, and observations about the caudal adhesive pads in individuals with bifurcated tails. Our observations represent a new case of caudal bifurcation for lizard species that have tails with functional specializations and elaborate morphological structures and are the first records of this type of anomaly for the genus Lygodactylus.

Key words: Autotomy; Lizards; Tail anomalies; Tail regeneration 
Lizards have the noteworthy ability to regenerate their broken tails, which involves repairing several damaged tissues, including muscular, osteological, and neuronal (ALIBARDI, 2010). This regeneration is essential to ensure the survival of lizards, since individuals without regenerated tails may experience a reduction in individual fitness for some behavioral aspects, such as habitat selection, foraging, antipredatory behavior, and social and reproductive issues (see review in BATEMAN; FLEMING, 2009). However, the regeneration is not always perfect and there are many records of tail abnormalities, such as the appearance of warped, curly, or supernumerary tails (MEYER et al., 2002; PASSOS et al., 2016). Incomplete autotomy or tail injuries can stimulate the regeneration of additional tails (DUDEK; EKNER-GRZYB, 2014; KOLENDA et al., 2017; RAMADANOVIC; ZIMIC, 2019) and have been reported in different lizard families, for example, Dactyloidae (e.g., TIPANTIZA-TUGUMINAGO et al., 2019), Gekkonidae (e.g., GARCÍA-VINALAY, 2017), Iguanidae (e.g., ARIANO-SÁNCHEZ; GILESCOBEDO, 2016), Lacertidae (e.g., KOLENDA et al., 2017), Phyllodactylidae (e.g., FILADELFO et al., 2017), Scincidae (e.g., MAGALHÃES et al., 2015), Teiidae (e.g., SALES; FREIRE, 2019), Tropiduridae (e.g., BRASILEIRO, 2021), Sphaerodactylidae (e.g., MOUADI et al., 2021) and others (see review in HENLE; GRIMM-SEYFARTH, 2020). Here we report the first cases of tail bifurcation in Lygodactylus klugei, which were recorded in two areas of the Caatinga domain in northeastern Brazil.

During studies carried out with the species, we recorded two cases of an individual with a bifid tail. The first specimen was an adult female (CHUFCL 7260; SVL $=27.9 \mathrm{~mm}$, Figure 1A, 1B) collected on July 6, 2018 , in the municipality of Pentecoste $(-3.81843 \mathrm{~S}$, -39.33923 W; 65 m a.s.1.), Ceará, Brazil. The bifurcation occurred $19.37 \mathrm{~mm}$ posterior to the cloaca. The first branch was $5.1 \mathrm{~mm}$ long and a second branch was 3.57 $\mathrm{mm}$ long. Both branches were uniform in color, with no apparent differentiation of the scales. The second specimen was an adult male (CHUFCL 7319; SVL = $25.55 \mathrm{~mm}$, Figure 1C) collected on July 18, 2018, in the municipality of Patos (-7.05974 S, $-37.27507 \mathrm{~W} ; 251 \mathrm{~m}$

FIGURE 1: Individuals of L. kluguei with tail bifurcations. Female captured in Pentecoste, Ceará (A, B). Male captured in Patos, Paraiba (with autotomized tail during capture) (C).

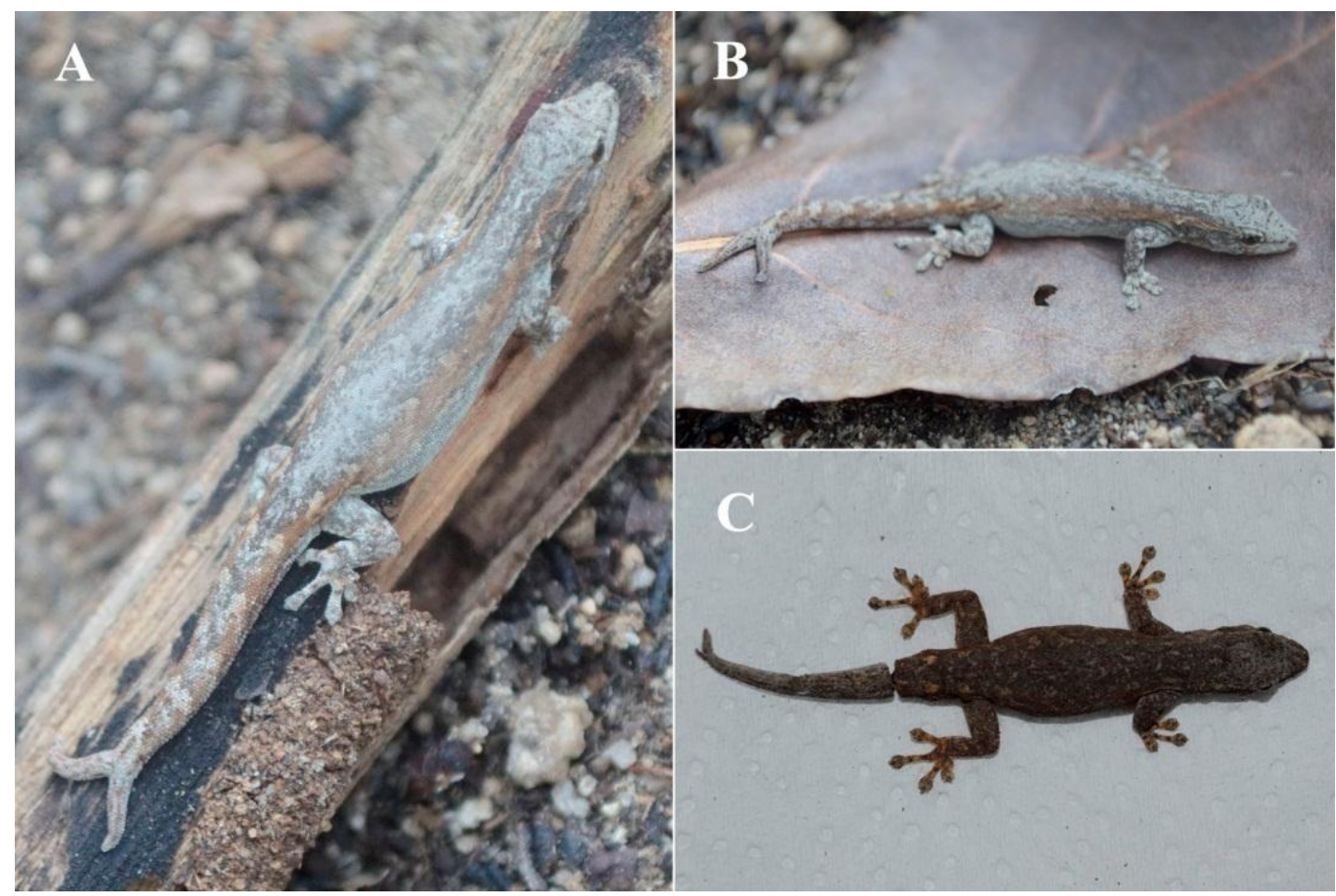


a.s.1), Paraíba, Brazil. In this case, the bifurcation was very inconspicuous and located in the terminal portion of the tail, $17.52 \mathrm{~mm}$ posterior to the cloaca. The longest branch was $2.06 \mathrm{~mm}$, and the second branch was 1.16 $\mathrm{mm}$ and darker.

According to Alibardi (2010), these deformities can be caused by incomplete caudal autotomy, as well as by a crushed spinal cord and ependymal within the tail. Although it is not possible to confirm this with our data, we suggest that both cases of bifurcation were derived from previous injuries where there was incomplete autotomy, but the damage was sufficient to start the process of regeneration and growth of a new tail in the affected places (DUDEK; EKNER-GRZYB, 2014), which resulted in a supernumerary tail in each individual.

The tip of the tail of L. klugei has specialized glandular structures similar to the adhesive pads found on the fingers (SMITH et al., 1977). Studies using scanning electron micrographs report that the regenerated tail in this species has the same structures and performs the same functions as the original tail, although there are imperfections (VITT; BALLINGER, 1982). Although we did not investigate the ultrastructure of the region, we did not observe adhesive pads on any of the caudal branches of both individuals at macroscopic levels (Figure 2A-D). The visual absence of these structures compared to the original tails in other individuals (Figure 2E) leads us to believe that the bifurcation processes described here occurred in previously regenerated tails.

Although there are no studies on the effects caused by supernumerary tails, occasional reports suggest that the presence of these anomalies can negatively affect the fitness of individuals, but without apparent changes in survival rates (see HENLE; GRIMM-SEYFARTH, 2020). Visually, we did not observe any type of locomotor deficiency or difficulty in escaping during the capture process of both individuals compared to other $L$. klugei specimens with non-bifurcated tails. Although tail loss can impair the ability to escape on vertical surfaces

FIGURE 2: Details of bifurcations. Dorsal (A) and ventral (B) view of the female (CHUFCL7260). Dorsal (C) and ventral (D) view of the male (CHUFCL7319). Dorsal view of the tail of a third individual with intact tail (without previous autotomies), with emphasis on the caudal adhesive pads (E).

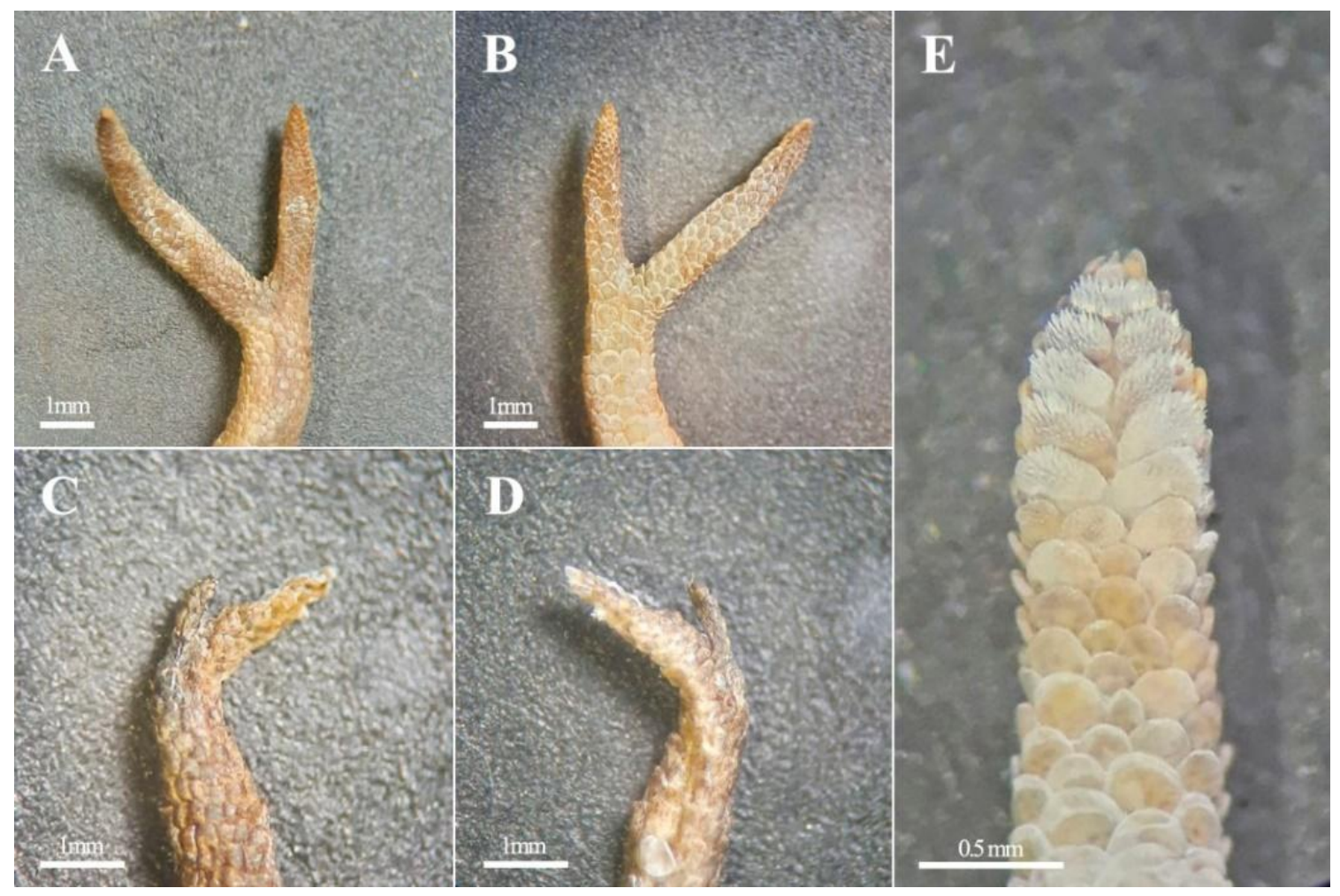


in Lygodactylus (VITT; BALLINGER, 1982; MEDGER et al., 2008), the effects of multiple tails with additional adhesive structures, and whether these are functional in the natural environment, are still unknown.

During our studies developed over a year in 12 populations of L. klugei, 249 individuals were captured. The findings of bifurcated tails described here represent an occurrence of $0.8 \%$, a value similar to those found for some lizard populations, such as Ophisops elegans Ménétries, 1832 (TAMAR et al., 2013), Lacerta agilis Linnaeus, 1758 (KOLENDA et al., 2017), Ablepharus kitaibelii Bibron \& Bory St-Vincent, 1833 (VERGILOV; NATCHEV, 2017), Ameivula ocellifera (Spix, 1825) (SALES; FREIRE, 2019), Psychosaura macrorhyncha (Hoge, 1946) (VRCIBRADIC; NIEMEYER, 2013), and others (see HENLE; GRIMM-SEYFARTH, 2020). When we analyze the populations of L. klugei from this research independently, the total number of individuals sampled in each location corresponds to 23 and 21 for the Patos and Pentecoste populations, respectively. In addition to the results obtained by Henle and GrimmSeyfarth (2020), the cases described here are a new record of tail bifurcation for lizard species that have tails with functional specializations and elaborate morphological structures and are also the first reports of this type of anomaly for the genus Lygodactylus.

\section{Acknowledgments}

We are grateful to the Núcleo Regional de Ofiologia at the Universidade Federal do Ceará, which provided logistical support for the development of our research. This work was supported by the Conselho Nacional de Desenvolvimento Científico e Tecnológico (CNPq) Projeto Universal 430030/2016-9.

\section{References}

ALIBARDI, L. Morphological and cellular aspects of tail and limb regeneration in lizards: a model system with implications for tissue regeneration in mammals. Advances in Anatomy, Embryology and Cell Biology, Berlin, v. 207, p. 1-109, 2010.

ARIANO-SÁNCHEZ, D.; GIL-ESCOBEDO, J. Ctenosaura palearis (Guatemala spiny-tailed iguana). Tail trifurcation. Herpetological Review, Walnut Ridge, v. 47, p. 463-464, 2016.
BATEMAN, P. W.; FLEMING, P. A. To cut a long tail short: a review of lizard caudal autotomy studies carried out over the last 20 years. Journal of Zoology, London, v. 277, p. 1-14, 2009.

BRASILEIRO, A. C. Tail bifurcation in Tropidurus hispidus (Spix, 1825) and Copeoglossum nigropunctatum (Spix, 1825). Herpetology Notes, Victorville, v. 14, p. 601-603, 2021.

DUDEK, K.; EKNER-GRZYB, A. Field observation of two-tailed sand lizard Lacerta agilis Linnaeus, 1758 and a common lizard Zootoca vivipara (Jacquin, 1787) in Poland. Natura Sloveniae, Ljubljana, v. 16, p. 65-66, 2014.

FILADELFO, T.; SOEIRO, M.; PINTO-COELHO, D.; HAMDAN, B. Phyllopezus pollicaris (Brazilian gecko). Tail bifurcation. Herpetological Review, Walnut Ridge, v. 48, p. 656, 2017.

GARCÍA-VINALAY, A. Hemidactylus frenatus Duméril \& Bibron, 1836. Tail bifurcation. Mesoamerican Herpetology, Eagle Mountain, v. 4, p. 635-637, 2017.

HENLE, K.; GRIMM-SEYFARTH, A. Exceptional occurrences of double, triple and quintuple tails in an Australian lizard community, with a review of supernumerary tails in natural populations of reptiles. Salamandra, Bad Münstereifel, v. 56, n. 4, p. 373-391, 2020.

KOLENDA, K.; WIECZOREK, M.; NAJBAR, A.; NAJBAR, B.; SKAWIŃSKI, T. Limb malformation and tail bifurcation in sand lizards (Lacerta agilis) and common lizards (Zootoca vivipara) from Poland. Herpetology Notes, Victorville, v. 10, p. 713-716, 2017.

MAGALHÃES, F. M.; CAMURUGI, F.; SILVEIRA-FILHO, R. R.; MÂNGIA, S.; CONCEIÇÃO, B. M. Brasiliscincus heathi (Brazilian mabuya). Tail bifurcation. Herpetological Review, Walnut Ridge, v. 46, n. 4, p. 624-625, 2015.

MEDGER, K.; VERBURGTM L.; BATEMAN, P. W. The influence of tail autotomy on the escape response of the Cape Dwarf Gecko, Lygodactylus capensis. Ethology, Weinheim, v. 114, p. 42-52, 2008.

MEYER, V.; PREEST, M. R.; LOCHETTO, S. M. Physiology of original and regenerated lizard tails. Herpetologica, Nacogdoches, v. 58, p. 75-86, 2002.

MOUADI, J.; ELBAHI, A.; ER-RUIBI, O.; LAGHZAOUI, E-M.; AGLAGANE, A.; AAMIRI, A.; EL MOUDEN, E. H.; AOURIR, M. First record of abnormal tail regeneration in the Moroccan endemic gecko, Quedenfeldtia trachyblepharus (Boettger, 1874), and for the family Sphaerodactylidae. Herpetology Notes, Victorville, v. 14, p. 959-963, 2021.

PASSOS, D. C.; FONSECA, P. H. M.; DE VIVAR, P. R. R.; KANAYAMA, C. Y.; TEIXEIRA, V. P.; MARTINELLI, A. G. Tail trifurcation in the lizard Salvator merianae (Squamata: Teiidae) investigated by computer tomography. Phyllomedusa: Journal of Herpetology, Piracicaba, v. 15, n. 1, p. 79-83, 2016.

RAMADANOVIC, D.; ZIMIC, A. Record of a Lacerta agilis Linnaeus, 1758 with erythronotus colour morph and tail bifurcation. Herpetology Notes, Victorville, v. 12, p. 779-781, 2019.

SALES, R. F. D.; FREIRE, E. M. X. Ameivula ocellifera (Spix's Whiptail). Tail bifurcation. Herpetological Review, Walnut Ridge, v. 50, n. 4, p. 780, 2019. 
SMITH, H. M.; MARTIN, R. L.; SWAIN, T. A. A new genus and two new species of south American geckos (Reptilia: Lacertilia). Papeis Avulsos de Zoologia, São Paulo, v. 30, p. 195-213, 1977.

TAMAR, K.; MAZA, E.; MEIRI, S. Ophisops elegans (Snake-eyed lizard). Bifurcation. Herpetological Review, Walnut Ridge, v. 44, n. 1, p. 146, 2013.

TIPANTIZA-TUGUMINAGO, L.; BRITO-ZAPATA, D.; MEDRANO-VIZCAÍNO, P. Anolis fitchi (Fitch's anolis). Tail bifurcation. Herpetological Review, Walnut Ridge, v. 50, p. 781$782,2019$.
VERGILOV, V.; NATCHEV, N. First record of tail bifurcations in the snake-eyed skink Ablepharus kitaibelii Bibron \& Bory de Saint-Vincent, 1833 from Pastrina hill (northwestern Bulgaria). Arxius de Miscel·lània Zoològica, Barcelona, v. 15, p. 224-228, 2017.

VITT, L. J.; BALLINGER, R. E. The adaptive significance of a complex caudal adaptation in the tropical gekkonid lizard Lygodactylus klugei. Canadian Journal of Zoology, Ottawa, v. 60, p. 2582-2587, 1982.

VRCIBRADIC, D.; NIEMEYER, J. Mabuya frenata, $M$. macrorhyncha, tail bifurcation. Herpetological Review, Walnut Ridge, v. 44, p. 510-511, 2013. 